\title{
Comparison of Food Intake and Height Increment in Normal and Constitutionally Short Children and in Children with Growth Hormone Deficiency
}

\author{
Yoshiaki OKADA ${ }^{1}$, KazUo WATANABE ${ }^{2}$, TORU TAKEUCHI ${ }^{2}$, \\ TOSHIO ONISHI ${ }^{1}$, KIYOJI TANAKA ${ }^{1}$, MitSuKo TSUJI ${ }^{1}$, \\ SHIGETO MORIMOTO ${ }^{1}$ AND YUICHI KUMAHARA ${ }^{1}$ \\ ${ }^{1}$ Department of Medicine and Geriatrics Osaka University School \\ of Medicine 50-1-1, Fukushima-ku, Osaka 553, Japan and \\ ${ }^{2}$ Yodogawa Christian Hospital 57-1, Awajihonmachi, \\ Higashi-Yodogawa-ku, Osaka 533, Japan
}

\section{Synopsis}

The relation between height increment and food intake in 21 growth-hormonedeficient patients was studied in comparison with 10 normal and 13 constitutionally short children. Total calory of food intake and height increment were $64.6 \pm 18.6$ $\mathrm{Cal} / \mathrm{kg} /$ day and $7.31 \pm 2.53 \mathrm{~cm} /$ year in normal children, $71.4 \pm 17.7 \mathrm{Cal} . / \mathrm{kg} / \mathrm{day}$ and $6.13 \pm 1.52 \mathrm{~cm} /$ year in constitutionally short children and $64.59 \pm 29.14 \mathrm{Cal} / \mathrm{kg} / \mathrm{day}$ and $5.29 \pm 1.11 \mathrm{~cm} /$ year in $\mathrm{HGH}$-deficient patients who were given $\mathrm{HGH}$ at a small dose ranging from 0.17 to $0.375(0.248 \pm 0.064) \mathrm{IU} / \mathrm{kg} / \mathrm{week}$. Distribution of carbohydrate, protein and fat did not show any significant difference in relation to the total calory. A significant correlative relation between food intake and height increment was noted in normal children $(\mathrm{r}=0.748 \mathrm{p}<0.01)$ and in children with constitutionally short stature $(r=0.7005 p<0.005)$. Food intake by which to be able to expect normal prepubertal or pubertal growth is likely to be more than $47.3 \mathrm{Cal} / \mathrm{kg} / \mathrm{day}$. In a group of $16 \mathrm{HGH}$-deficient patients who had food intake ranging from 26.9 to 78 $\mathrm{Cal} / \mathrm{kg} /$ day, a significant correlation between food intake and height increment was observed $(r=0.473 \mathrm{p}<0.05)$, but in 5 patients who had food intake with more than 80 $\mathrm{Cal} / \mathrm{kg} /$ day, height increment was not related to food intake but ranged from 5.4 to $6.3 \mathrm{~cm} /$ year. In a group of $\mathrm{HGH}$-deficient patients who had food intake ranging from 26.9 to $78 \mathrm{Cal} / \mathrm{kg} / \mathrm{day}$, the food intake of 9 responders to $\mathrm{HGH}(56.55 \pm 10.34$ $\mathrm{Cal} / \mathrm{kg} /$ day) was significantly more than that of 7 non-responders to $\mathrm{HGH}$ treatment $(42.0 \pm 11.8 \mathrm{Cal} / \mathrm{kg} /$ day), despite no statistically significant difference in $\mathrm{HGH}$ dose between responders and non-responders. These data suggest that the decreased food intake is one of the causative factors which induce unresponsiveness to $\mathrm{HGH}$ in HGH-deficient children who are treated with a small dose of HGH.

Treatment of growth-hormone-deficient children has been widely investigated since human growth hormone ( $\mathrm{HGH})$ was available in 1959. It is well known that the response to $\mathrm{HGH}$ depends upon the duration of the treatment (Storment et al., 1968), the bone age (Tanner et al., 1971), the ap-

\footnotetext{
Received June 30, 1978.

This study was supported in part by research grants from the Ministry of Education, Science and Culture, and the Ministry of Welfare, Japan.
}

pearance of antibodies to HGH (Illig, 1972) and the dose (Preece et al., 1977). However, the influence of nutrition on the growth rate of children treated with $\mathrm{HGH}$ has not been documented. This paper describes the relation between food intake and height increment per year in $\mathrm{HGH}-$ deficient patients treated with $\mathrm{HGH}$ preparations, comparing the height increment of normal children and that of children with constitutionally short stature. 


\section{Materials and Methods}

Twenty one HGH-deficient patients from 5 to 18 years of age were studied. Their bone age was less than 15 years. The diagnostic criteria for $\mathrm{HGH}$ deficient patients are 1) the well-proportioned stature shorter than -2.5 S.D., 2) the ratio of bone age to chronological age less than $0.8,3$ ) the maximum level of serum $\mathrm{HGH}$ in two of the there testsinsulin tolerance test, arginine test and propranololglucagon test less than $5 \mathrm{ng} / \mathrm{ml}$ and 4) the height increment for 3 years less than $12 \mathrm{~cm}$. Patients who exhibited hypothyroid state or in whom $\mathrm{HGH}$ antibodies were detected during the treatment were excluded from this study. Patients who showed sexual development during $\mathrm{HGH}$ treatment were also excluded from this study to omit the heterogeniety of a small group of patients from 5-18 years of age. The dose of $\mathrm{HGH}$ ranged from 0.17 to $0.375(0.259 \pm 0.06) \mathrm{IU} / \mathrm{kg} /$ week. Body weight ranged from 87 to $153.4(110.4 \pm 16.72) \%$ compared with normal weight corresponding to their height age. Food intake was studied for one week and mean calory intake per $\mathrm{kg}$ of body weight was calculated. The patients were requested to visit our hospital monthly and checked for their height, weight, $\mathrm{HGH}$ antibodies and thyroid function. The distribution of carbohydrate, protein and fat was expressed as percentage of total calory. The diet analysis and measurement of height increment were performed during the second and third year of treatment. Ten normal children from 5 to 13 years of age and 12 children with constitutionally short stature from 5 to 15 years of age were also studied as control subjects. The mean and standard deviation of serum thyroxine and triiodothyroinine levels was $8.81 \pm 3.16 \mu \mathrm{g} / 100 \mathrm{ml}$ and $126 \pm 38.4 \mathrm{ng} / 100$ $\mathrm{m} l$ in normal children, $8.12 \pm 2.7 \mu \mathrm{g} / 100 \mathrm{~m} l$ and 138 $\pm 48.6 \mathrm{ng} / 100 \mathrm{ml}$ in children with constitutionally short stature and $7.92 \pm 4.31 \mu \mathrm{g} / 100 \mathrm{~m} l$ and $148 \pm 41.4$ $\mathrm{ng} / 100 \mathrm{ml}$ in patients with $\mathrm{HGH}$ deficiency, respectively.

\section{Results}

\section{Normal children}

The total calory intake ranged from 38.7 to 91.1 (Mean \pm S.D., $64.6 \pm 18.6$ ) Cal $/ \mathrm{kg}$ of body weight/day, and the distribution of carbohydrate, protein and fat in total calory was $59.6 \pm 10.34,17.95 \pm 5.29$ and $22.37 \pm 5.38 \%$, respectively. These distribution percentages did not show any signi- ficant difference in relation to the total calory intake ranging from 38.7 to 91.1 $\mathrm{Ca} / \mathrm{kg} /$ day. Height increment ranged from 4.9 to $13.0(7.31 \pm 2.53) \mathrm{cm} /$ year. A significant correlation between height increment and food intake was noted $(\mathrm{r}=0.748, \mathrm{p}<$ $0.01)$ as shown in Fig. 1.

\section{Constitutionally short children}

The total calory intake ranged from 47.1 to $102.3(71.4 \pm 17.7) \mathrm{Cal} / \mathrm{kg}$ of body weight per day and the distribution of carbohydrate, protein and fat was $61.17 \pm 7.22$,

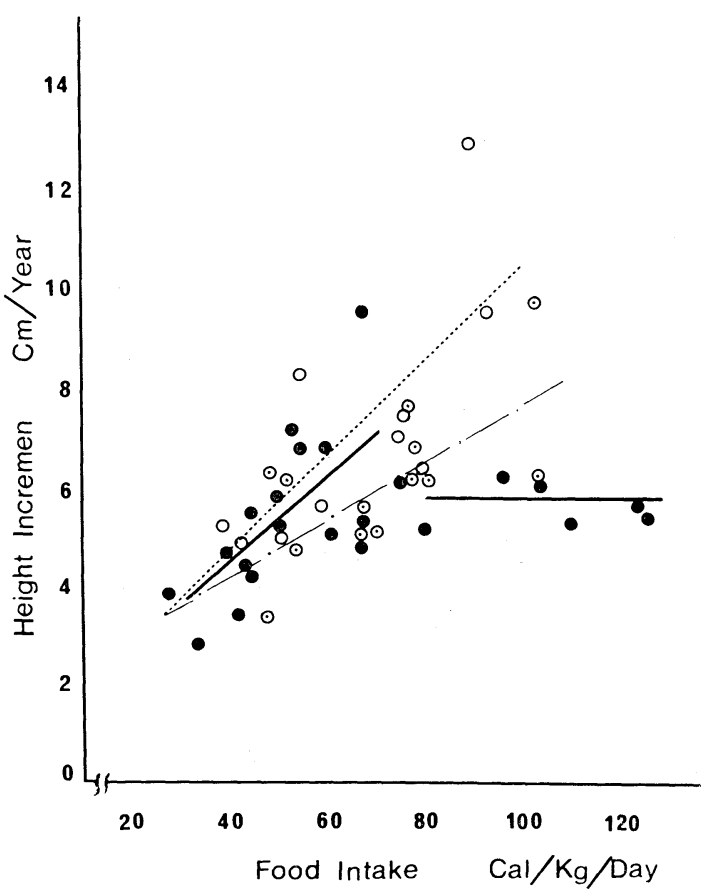

Fig. 1. Relation between height increment and food intake in 10 normal children (O), in 13 children with constitutionally short stature $(\odot)$ and in 21 children with $\mathrm{HGH}$ deficiency (-). Height increment correlated with food intake in normal children ( $\mathrm{r}=0.748, \mathrm{P}<0.01, \mathrm{Y}=0.102 \mathrm{X}+0.748,----)$ ) and in children with constitutionally short stature ( $\mathrm{r}=$ $0.7005, \mathrm{P}<0.05, \mathrm{Y}=0.0627 \mathrm{X}+1.653-\cdot-\cdot-\cdot-)$. In children with $\mathrm{HGH}$ deficiency, however, height increment correlated with food intake at the range form 26.9 to $78 \mathrm{Cal} / \mathrm{kg}$ of body weight/day ( $\mathrm{r}=$ $0.473, \mathrm{P}<0.01, \mathrm{Y}=0.044 \mathrm{X}+2.911-$ ), but not at the range of more than $80 \mathrm{Cal} / \mathrm{kg} /$ day. 
$14.82 \pm 2.69$ and $24.08 \pm 5.78 \%$, respective1y. Height increment ranged from 3.4 to $9.8(6.13 \pm 1.52) \mathrm{cm} /$ year. A significant correlation between height increment and food intake was also noted $(\mathrm{r}=0.7005, \mathrm{p}<$ 0.005 ) as shown in Fig. 1. In the relation between height increment $(\mathrm{Y}, \mathrm{cm} /$ year $)$ and food intake (X, Cal $/ \mathrm{kg} /$ day) of control subjects, the formula of regression line $(r=$ $0.68, \mathrm{p}<0.01$ ) was $\mathrm{Y}=0.09 \mathrm{X}+0.74$. The food intake necessary for normal height increment of more than $5 \mathrm{~cm} /$ year was calculated from this formula to be more than $47.3 \mathrm{Cal} / \mathrm{kg} /$ day.

\section{Patients with HGH-deficiency}

The total calory intake was $64.59 \pm 29.14$ $\mathrm{Cal} / \mathrm{kg}$ of body weight/day. The distribution of carbohydrate, protein and fat was $62.0 \pm 8.83,17.17 \pm 4.54$ and $20.80 \pm 6.09 \%$, respectively. This distribution did not show any significant difference in relation to the total calory intake ranging from 26.9 to $123.7 \mathrm{Cal} / \mathrm{kg} /$ day. Height increment per year on HGH at the dose of $0.248 \pm 0.064$ $\mathrm{IU} / \mathrm{kg} /$ week ranged from 2.9 to $7.2(5.29 \pm$ 1.11). It was more than $5 \mathrm{~cm} /$ year in 14 cases (responders) and less in 7 cases (non-responders). There was no correlation between height increment and the dose of $\mathrm{HGH}$ in the 21 patients studied. However, height increment correlated with food intake $(\mathrm{Cal} / \mathrm{kg})$ significantly $(\mathrm{p}<0.01, \mathrm{r}=$ 0.473) when the toal food intake ranged from 26.9 to $78 \mathrm{Cal} / \mathrm{kg}$, but it was between 5.4 and $6.3 \mathrm{~cm} /$ year even when food intake increased to more than $80 \mathrm{Cal} / \mathrm{kg}$, as shown in Fig. 1. In case that 5 patients who had more than $80 \mathrm{Cal} / \mathrm{kg} /$ day of food were excluded from statistical analysis, the $\mathrm{HGH}$ dose in 7 non-responders (0.216士 0.052 ) did not differ statistically from that in 9 responders $(0.271 \pm 0.073 \mathrm{IU} / \mathrm{kg} /$ week $)$. The mean total food intake of the nonresponders $(42.0 \pm 11.8 \mathrm{Cal} / \mathrm{kg})$ was significantly lower $(p<0.01)$ than that of the responders $(56.55 \pm 10.34 \mathrm{Cal} / \mathrm{kg})$. There was no correlation between height increment and protein intake both in $\mathrm{HGH}-$ deficient patients and in control subjects as shown in Fig. 2. The food intake of HGH-deficient patients did not correlate with the HGH dose.

\section{Discussion}

It might be an over-estimation to speculate the relation of height increment $(\mathrm{cm} /$ year) to food intake (Cal $/ \mathrm{kg} /$ day), since the former was the result of one whole year and the latter that of one week. A significant correlation, however, between height increment and food intake in control subjects suggests that food intake is one of the factors which are directly or indirectly related to growth at the age before late

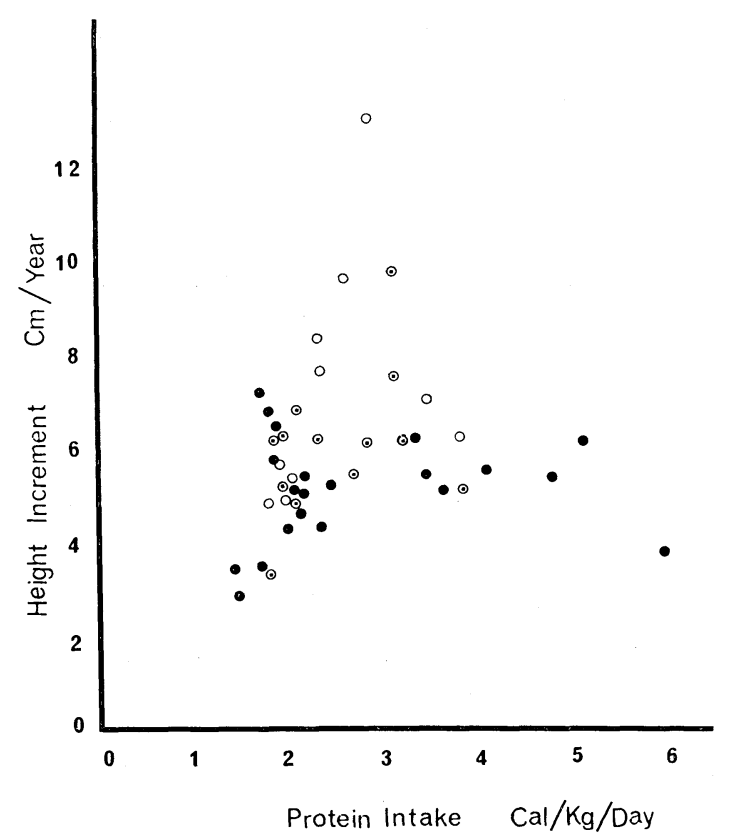

Fig. 2. Relation between height increment and protein intake in 10 normal children (O), in 13 children with constitutionally-short stature $(\odot)$, and 21 in children with $\mathrm{HGH}$ deficiency $(\bullet)$. Height increment did not correlate with protein intake either in normal and constitutionally short children or in $\mathrm{HGH}$-deficient children. 
puberty. Our data suggest that food intake of more than $47.3 \mathrm{Cal} / \mathrm{kg} /$ day of body weight is necessary for prepubertal or pubertal growth not only in normal children but also in HGH-deficient patients who are given $\mathrm{HGH}$. In patients with $\mathrm{HGH}-$ deficiency, height increment was significantly low in patients with low calory intake despite no statistically significant difference in HGH dose between responders and nonresponders to $\mathrm{HGH}$ administration. The reason why the height increment of $\mathrm{HGH}$ deficient patients who had more than 80 $\mathrm{Ca} / \mathrm{kg} /$ day of food intake did not increase correlatively with food intake is probably that they did not have as much as 80 $\mathrm{Cal} / \mathrm{kg} / \mathrm{day}$ through the whole year or, even if they had, the $\mathrm{HGH}$ dose given them was limited to less than $0.737 \mathrm{IU} / \mathrm{kg} /$ week. Therefore, it should be emphasized that the decreased food intake is one of the causative factors which induce a spontaneous unresponsiveness to the administration of a small dose of HGH.

It is quite natural that growth depends upon the existence of growth-promoting hormones and their biological activities, intermediating cell growth factors, on peripheral tissues such as bone and muscle. However, nutrition may have some influence on the activity of somatomedin, since animal experiments suggest that starvation induced a decrease in somatomedin activity (Daughaday and Kipnis, 1966; Philips and Young, 1976). According to the experimental results of Takano et al. (1978), however, somatomedin A level correlated with total food intake in rats, but not with protein intake. This is compatible with our results that the height increment of children treated with $\mathrm{HGH}$ is likely related to the total food intake. It seems apparent, however, that somatomedin activity is correlated with serum insulin level more than with growth hormone levels in animal experiments (Philips and Kipnis, 1977). Therefore, further investigation on insulin secretion will be needed in order to see if there is any difference in glucose metabolism of responders and non-responders to $\mathrm{HGH}$ administration.

\section{Acknowledgements}

We are grateful to Mrs. Mollie Moore, Mrs. Masako Tanaka and Miss Eiko Kawagoe for their help in preparation of the manuscript.

\section{References}

Daughaday, W. H. and D. M. Kipnis (1966). Rec. Prog. Hor. Res. 22, 49.

Illig, R. Human Growth Hormone (edited by A. S. Mason), William Heinemann Medical Books Ltd., p. 144. (1972).

Phillips, L. S. and H. S. Young (1976). Endocrinology 99, 304.

Phillips, L. S. and H. S. Kipnis (1977). Nutrition Reviews 35, 150.

Preece, M. A., J. M. Tanner, R. H. Whitehouse and N. Cameron (1976). J. Clin. Endocrinol. Metab. 42, 477.

Storment, A. M. and F. R. Escamilla (1968). Modern Treat. 5, 13.

Takano, K., N. Hizuka, K. Kawai and K. Shizume (1978). Acta Endocrinol. (Kbh.) (in press)

Tanner, J. M., R. H. Whitehouse, P. C. R. Hughes. and F. P. Vince (1971). Arch. Dis. in Child. 46, 745. 